\title{
Brain Imaging of Nicotinic Receptors in Alzheimer's Disease
}

\author{
Jin Wu, Masatomo Ishikawa, Jichun Zhang, and Kenji Hashimoto \\ Division of Clinical Neuroscience, Center for Forensic Mental Health, Chiba University, 1-8-1 Inohana Chiba 260-8670, Japan \\ Correspondence should be addressed to Kenji Hashimoto, hashimoto@faculty.chiba-u.jp
}

Received 30 October 2010; Accepted 8 December 2010

Academic Editor: Adam S. Fleisher

Copyright ( 2010 Jin Wu et al. This is an open access article distributed under the Creative Commons Attribution License, which permits unrestricted use, distribution, and reproduction in any medium, provided the original work is properly cited.

\begin{abstract}
Neuronal nicotinic acetylcholine receptors (nAChRs) are a family of ligand-gated ion channels which are widely distributed in the human brain. Several lines of evidence suggest that two major subtypes $(\alpha 4 \beta 2$ and $\alpha 7)$ of nAChRs play an important role in the pathophysiology of Alzheimer's disease (AD). Postmortem studies demonstrated alterations in the density of these subtypes of nAChRs in the brain of patients with AD. Currently, nAChRs are one of the most attractive therapeutic targets for AD. Therefore, several researchers have made an effort to develop novel radioligands that can be used to study quantitatively the distribution of these two subtypes in the human brain with positron emission tomography (PET) and single-photon emission computed tomography (SPECT). In this paper, we discuss the current topics on in vivo imaging of two subtypes of nAChRs in the brain of patients with $\mathrm{AD}$.
\end{abstract}

\section{Introduction}

Alzheimer's disease (AD) is the most common neurodegenerative disorder in the elderly and has become a major worldwide health problem. Several reports indicated that it is affecting almost 1 in 10 individuals over the age of 65 [1], and as life expectancy increases, over 37 million people suffer with $\mathrm{AD}$, and it is projected to quadruple by 2050 [2]. AD accounts for over $50 \%$ of senile dementia and the majority of presenile dementia cases and is characterized by progressive deterioration of higher cognitive functions including the loss of memory $[3,4]$.

van Duijn and Hofman [5] reported the inverse relationship between smoking history and early onset AD, suggesting that smoking may protect against AD [6]. Furthermore, Rusted and Trawley [7] reported acute improvements in prospective memory following nicotine administration. Although Swan and Lessov-Schlaggar [8] discuss the effects of tobacco smoke and nicotine on cognition in their review, smoking is associated with increased risk for negative preclinical and cognitive outcomes in younger people as well as in older adults. More recently, a meta-analysis including longitudinal studies published between 1995 and 2007 reported that current smokers relative to never-smokers were at increased risk of $\mathrm{AD}$, vascular dementia, any dementia, and cognitive decline, in over the age of 65 [9]. Several lines of evidence demonstrated that smoking almost doubled the risk of $\mathrm{AD}$ and that smoking cessation might contribute to a reduction of risk factors for $\mathrm{AD}$ and cardiovascular disease $[10,11]$. Noteworthy, the later is also known as a risk factor for AD. These results suggest that smoking cessation may play an important role in not only primary but also secondary prevention of $\mathrm{AD}$. In contrast, although the discussion about neuroprotection by smoking has been continued, it is possible that nicotinic acetylcholine receptors (nAChRs) in the brain might play a role in the pathophysiology of AD.

The nAChRs are one of the main classes of AChRs, which have a pentameric structure composed of five membrane spanning subunits, of which nine different types have thus far been identified and cloned. To date, twelve neuronal $\mathrm{nAChR}$ subunits have been described [12]; nine $(\alpha 2-\alpha 10)$ code for subunits [12] based on the presence of adjacent cysteine residues in the predicted protein sequences, in a region homologous to the putative agonist-binding site of the muscle, a subunit $(\alpha 1)$ and three referred to as non- $\alpha$ or $\beta$ subunits $(\beta 2-\beta 4)$. Among the several $\mathrm{nAChR}$ subtypes in the human central nervous system (CNS), the heteromeric $\alpha 4 \beta 2$ and homomeric $\alpha 7$ subtypes (Figure 1) are predominant in the brain $[13,14]$. It has been reported that other subtypes (e.g., $\alpha 3, \alpha 6$ ) exist in the brain $[15,16]$ and that $\alpha 6$ subtype 


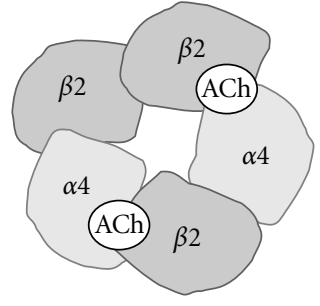

$\alpha 4 \beta 2$ subtype

(a)

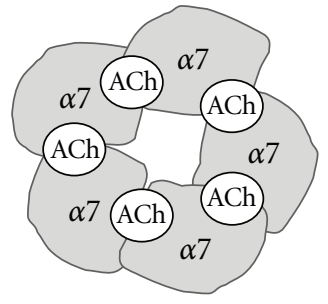

$\alpha 7$ subtype

(b)
FIGURE 1: Structures of $\alpha 4 \beta 2 \mathrm{nAChR}$ (a) and $\alpha 7 \mathrm{nAChR}$ (b).

might be mainly involved in the pathophysiology of Parkinson's disease [16]. Furthermore, studies using postmortem human brain samples have demonstrated alterations in the levels of $\alpha 4$ and $\alpha 7 \mathrm{nAChR}$ in the brains of patients with $\mathrm{AD}[15,17-19]$. Despite its lower number, loss of $\alpha 3$ subtype consistent with $\alpha 4$ and $\alpha 7 \mathrm{nAChR}$ subtypes was also observed in the brains of patients with $\mathrm{AD}$ [15]. Taken together, it is likely that these two subtypes $(\alpha 4 \beta 2$ and $\alpha 7)$ of nAChR might play a role in the pathogenesis of AD. Therefore, it is of great interest to examine whether these two subtypes of $\mathrm{nAChR}$ are altered in the living brain of patients with $\mathrm{AD}$ using brain imaging techniques.

In this paper, we discuss the recent findings on imaging of these two nAChRs ( $\alpha 4 \beta 2$ and $\alpha 7$ ) in the brain with $\mathrm{AD}$ using positron emission tomography (PET) and singlephoton emission computed tomography (SPECT).

\section{2. $\alpha 4 \beta 2$ nAChRs Subtype}

2.1. Relationship between Amyloid- $\beta$ and $\alpha 4 \beta 2 n A C h R$. Amyloid $\beta$ protein $(A \beta)$ is a major constituent of senile plaques and one of the candidates for the cause of the neurodegeneration found in $\mathrm{AD}$. It has been shown that the accumulation of $\mathrm{A} \beta$ precedes other pathological changes and causes neurodegeneration or neuronal death in vitro and in vivo $[20,21]$. The loss of memory seen in $\mathrm{AD}$ is thought to be associated with $\mathrm{A} \beta$-induced impairment of synaptic plasticity such as long-term potentiation (LTP) in the hippocampus. There are lines of evidence suggesting that $\mathrm{nAChR}$ activation provides protection against $\mathrm{A} \beta$-induced neurotoxicity in cultured cortical neurons $[22,23]$. These results indicated that nicotine protects against $A \beta$-induced neuronal death, and similar effect has been also observed in those selective $\alpha 4 \beta 2 \mathrm{nAChR}$ agonists such as cytosine and epibatidine, but this neuroprotection is blocked by the selective $\alpha 4 \beta 2 \mathrm{nAChR}$ antagonist dihydro- $\beta$-erythroidine $(\mathrm{DH} \beta \mathrm{E})$. Moreover, recently, Wu et al. [24] investigated a possible role of $\alpha 4 \beta 2 \mathrm{nAChR}$ in mediating the impairment of long-term potentiation (LTP) by various forms of $\mathrm{A} \beta$ in in vivo. They reported that intracerebroventricular injection of $A \beta_{40}, A \beta_{25--35}$, or $A \beta_{31--35}$ significantly suppressed highfrequency stimulation-induced LTP. Similarly, epibatidine dose dependently suppressed the induction of LTP. Whereas $\mathrm{DH} \beta \mathrm{E}$ showed no effect on the induction of LTP, it significantly reversed $A \beta_{31--35}$-induced LTP impairment.
These findings suggest that $\alpha 4 \beta 2 \mathrm{nAChR}$, which can be directly activated by $\mathrm{A} \beta$, is required for $\mathrm{A} \beta$ suppression of LTP in vivo. The mechanisms by which nicotine enhanced the inhibition of LTP by $A \beta$ were not clear. A possible explanation is that nicotine could activate nAChRs present in inhibitory interneurons, thereby potentiating inhibitory inputs to hippocampal neurons.

2.2. Cognition and $\alpha 4 \beta 2 n A C h R$ Agonists. It is likely that reduced density of $\mathrm{nAChR}$ is related to dementia severity, assessed using a global rating. Nicotine has been postulated to be a possible treatment for $\mathrm{AD}$, improving cognition in humans [25]. Recently, Loughead et al. [26] reported novel evidence that the $\alpha 4 \beta 2$ partial agonist varenicline increased working memory-related brain activity after 3 days of nicotine abstinence, particularly at high levels of task difficulty, with associated improvements in cognitive performance among highly dependent smokers.

2.3. Postmortem Studies of $\alpha 4 \beta 2 n A C h R$ in the Brain of Patients with $A D$. Not only transmitter release but also receptor-binding sites may be altered in the brain of $\mathrm{AD}$ patients [27-29]. Postmortem studies showed the reduction (up to $50 \%$ ) of $\alpha 4 \beta 2$ subtype of nAChRs in brain of patients with $\mathrm{AD}[30]$, and it may occur very early in the course of $\mathrm{AD}$ [31]. Both $\alpha 4$ and $\alpha 7$ subunits are known to be important constituents in $\alpha 4 \beta 2$ and $\alpha 7$ receptor subtypes, respectively. Investigation using the autopsy samples of human cerebral cortex has clearly shown that these two subtypes ( $\alpha 4$ and $\alpha 7$ isoforms) are significantly decreased in their protein amount in the cortices of $\mathrm{AD}$ patients $[15,19,32]$.

2.4. Imaging of $\alpha 4 \beta 2 n A C h R$ Subtype. Considering the role of $\alpha 4 \beta 2 \mathrm{nAChR}$ in the pathophysiology of $\mathrm{AD}$, it is of great interest to study $\alpha 4 \beta 2 \mathrm{nAChR}$ in the living human brain using PET/SPECT. Much effort has been devoted to visualize $\alpha 4 \beta 2 \mathrm{nAChR}$ in the brain by PET/SPECT. Currently, two PET ligands, including $\left[{ }^{11} \mathrm{C}\right]$ nicotine and $2-\left[{ }^{18} \mathrm{~F}\right]$ fluoro-3-(2 $(S)$ azetidinylmethoxy)pyridine $\left(2-\left[{ }^{18} \mathrm{~F}\right] \mathrm{F}-\right.$ $\mathrm{A}-85380)$, and a SPECT ligand, 5-[ $\left.{ }^{123} \mathrm{I}\right]$ iodo-3-(2 (S)-2azetidinylmethoxy)pyridine (5-[ $\left.\left.{ }^{123} \mathrm{I}\right] \mathrm{I}-\mathrm{A}-85380\right)$, (Figure 2) for in vivo imaging of $\alpha 4 \beta 2 \mathrm{nAChR}$ in the human brain have been used in clinical studies [33-35].

2.5. $\left[{ }^{11} \mathrm{C}\right]$ Nicotine. The development of radiolabelled nicotine [36, 37] has allowed for evaluating the uptake and distribution of nAChR in the living human brain [38-40]. The data obtained by $\left[{ }^{11} \mathrm{C}\right]$ nicotine is generally consistent with the known pattern of $\mathrm{nAChR}$ measured by in vitro binding in autopsy brain tissue [39]. [ $\left.{ }^{11} \mathrm{C}\right]$ nicotine-PET has been used to study $\alpha 4 \beta 2 \mathrm{nAChR}$ in human brain, and a severe loss of the $\mathrm{nAChR}$ has been detected in the brain of patients with $\mathrm{AD}$ [13]. Cortical nAChRs in mild AD patients are robustly associated with the cognitive function of attention [35] and have revealed a significant negative correlation between severity of cognitive impairment and density of brain $\mathrm{nAChR}$ [40]. It will be, therefore, of interest to study an alteration in $\alpha 4 \beta 2 \mathrm{nAChR}$ at a presymptomatic stage of AD. Furthermore, the in vivo cortical AChE inhibition and 


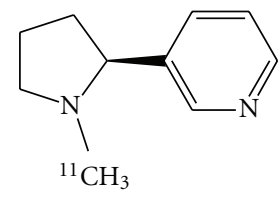

$\left[{ }^{11} \mathrm{C}\right](-)$ nicotine<smiles>[17CH2]c1ncccc1OC[C@@H]1CCN1</smiles>

$2-\left[{ }^{18} \mathrm{~F}\right] \mathrm{F}-\mathrm{A}-85380$

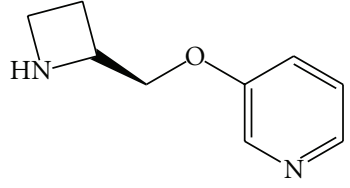

A-85380

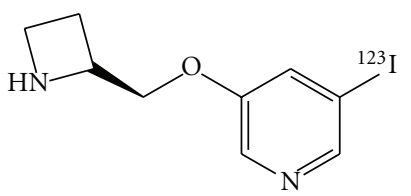

$5-\left[{ }^{123} \mathrm{I}\right] \mathrm{I}-\mathrm{A}-85380$

FIgURe 2: Chemical structures of radioligands for nAChRs.

$\left.{ }^{[1} \mathrm{C}\right]$ nicotine binding were associated with changes in the attention domain of cognition rather than episodic memory when administering galantamine $[41]$. Thus, $\left[{ }^{11} \mathrm{C}\right]$ nicotinePET may be also used for monitoring treatment efficacy in $\mathrm{AD}$ patients $[41,42]$.

Unfortunately, $\left[{ }^{11} \mathrm{C}\right]$ nicotine displays high levels of nonspecific binding, rapid metabolism, and rapid washout of the brain [43]. The heterogeneity of $\left[{ }^{11} \mathrm{C}\right]$ nicotine binding in the brain also precludes the identification of a reference region which may be used to accurately determine nonspecific binding. Taken together, it is unlikely that $\left[{ }^{11} \mathrm{C}\right]$ nicotine might be a suitable PET ligand for in vivo imaging of $\alpha 4 \beta 2$ $\mathrm{nAChR}$ in human brain.

2.6. $2-\left[{ }^{18} F\right] F-A-85380$ and $5-\left[{ }^{123} I\right] I-A-85380$. A-85380 [3$(2(S)$-azetidinylmethoxy) pyridine] is a potent and selective agonist with high affinity for $\alpha 4 \beta 2 \mathrm{nAChR}$ subtype and low affinity for other nAChR subtypes [44]. A-85380 is effective in a wide range of preclinical models of CNS disorders $[45,46]$. Recently, A-85380 was successfully labeled using ${ }^{18} \mathrm{~F}$ or ${ }^{125 / 123} \mathrm{I}$ with a high affinity $\left(K_{i}=50 \mathrm{pM}\right.$ for $\mathrm{F}$ and $K_{i}=15 \mathrm{pM}$ for I) for $\alpha 4 \beta 2 \mathrm{nAChR}[44,47,48]$. These radioligands have been evaluated in vitro and in vivo as PET/SPECT radioligands to visualize $\alpha 4 \beta 2 \mathrm{nAChR}$ subtype in the brain $[49,50]$. In healthy nonsmoking human brain, both $2-\left[{ }^{18} \mathrm{~F}\right] \mathrm{F}-\mathrm{A} 85380$ and $5-\left[{ }^{123} \mathrm{I}\right] \mathrm{I}-\mathrm{A} 85380$ have revealed a pattern of highest uptake in the thalamus, intermediate in the midbrain, pons, cerebellum, and cortex, and lowest in white matter [50-52], which is consistent with the regional distribution of $\alpha 4 \beta 2 \mathrm{nAChR}$.

Furthermore, a study of age-related decline in nicotinic receptor availability showed that regional $\beta 2 \mathrm{nAChR}$ availability were inversely correlated with decline ranging from $32 \%$ (thalamus) to $18 \%$ (occipital cortex) over the adult lifespan, or up to $5 \%$ per decade [53]. These results may corroborate postmortem reports of decline in high-affinity nicotine binding with age and may aid in elucidating the role of $\beta 2-\mathrm{nAChR}$ in cognitive aging. In addition, $2-\left[{ }^{18} \mathrm{~F}\right] \mathrm{F}-$ A-85380 or $5-\left[{ }^{123} \mathrm{I}\right] \mathrm{I}-\mathrm{A}-85380$ have been used to evaluate the effect of smoking on occupancy of $\alpha 4 \beta 2 \mathrm{nAChR}$ [54,

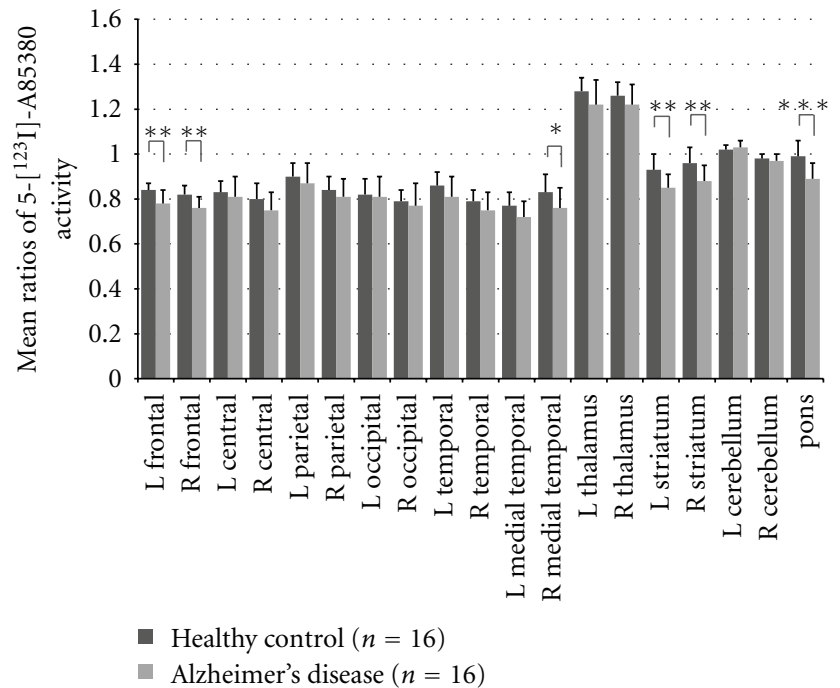

Figure 3: Comparison with regional uptake values of 5$\left[{ }^{123} \mathrm{I}\right] \mathrm{I}-\mathrm{A} 85380$ in age-matched healthy control and patients with Alzheimer's disease. Significant bilateral reductions in nicotinic receptor binding were identified in frontal, striatal, right medial temporal, and pons in patients with $\mathrm{AD}$ compared to controls. (Data is from the paper of $\mathrm{O}^{\prime}$ Brien et al. [59].) $* P<.05$, ${ }^{* *} P<.005$, *** $P<.001$.

55]. Smoking 0.13 (1 to 2 puffs) of a cigarette resulted in $50 \%$ occupancy of $\alpha 4 \beta 2$ nAChR for 3.1 hours after smoking. Smoking a full cigarette (or more) resulted in more than $88 \%$ receptor occupancy and was accompanied by a reduction in cigarette craving. The extent of receptor occupancy found herein suggests that smoking may lead to withdrawal alleviation by maintaining $\mathrm{nAChR}$ in the desensitized state.

Both 2- $\left[{ }^{18} \mathrm{~F}\right] \mathrm{F}-\mathrm{A}-85380$ and $5-\left[{ }^{123} \mathrm{I}\right] \mathrm{I}-\mathrm{A}-85380$ have been used in $\mathrm{AD}$ patients $[51,56-60]$. In 17 patients with moderate to severe AD and 6 subjects with amnestic mild cognitive impairment (MCI) compared with 10 healthy control subjects, Sabri et al. [56] found significant reductions of $\alpha 4 \beta 2 \mathrm{nAChR}$ in brain regions (hippocampus, caudate, frontal cortex, temporal cortex, posterior cingulate, anterior cingulate, and parietal cortex) in the brain of $\mathrm{AD}$ by using 2- $\left[{ }^{18} \mathrm{~F}\right] \mathrm{F}-\mathrm{A}-85380$. Most recently, Kendziorra et al. [57] reported that both patients with $\mathrm{AD}$ and those with $\mathrm{MCI}$ showed a significant reduction in $2-\left[{ }^{18} \mathrm{~F}\right] \mathrm{F}-\mathrm{A}-85380$ binding potential in typical $A D$-affected brain regions and that the 2$\left.{ }^{18} \mathrm{~F}\right] \mathrm{F}-\mathrm{A}-85380$ binding potential correlated with the severity of cognitive impairment. In addition, only MCI patients who converted to $\mathrm{AD}$ in the later course $(n=5)$ had a reduction in $2-\left[{ }^{18} \mathrm{~F}\right] \mathrm{F}-\mathrm{A}-85380$ binding potential. Thus, it is likely that $2-\left[{ }^{18} \mathrm{~F}\right] \mathrm{F}-\mathrm{A}-85380$ PET might give prognostic information about a conversion from MCI to AD. Similar findings were also reported by $5-\left[{ }^{123} \mathrm{I}\right] \mathrm{I}-\mathrm{A}-85380$, showing significant reductions in the activity ratios of the region of interest to cerebellum in the frontal, striatal, right medial temporal, and pontine regions in 16 patients with $\mathrm{AD}$ compared with 16 healthy control subjects [59] (Figure 3). These findings suggest that a reduction in $\alpha 4 \beta 2 \mathrm{nAChR}$ 
occurs during symptomatic stages of $\mathrm{AD}$ and that the $\alpha 4 \beta 2$ $\mathrm{nAChR}$ availability in these regions correlated with the severity of cognitive impairment. In contrast, there were no differences in distribution volume (DV) of nAChR between the healthy controls and early AD patients (Figure 4) [51, 58].

$2-\left[{ }^{18} \mathrm{~F}\right] \mathrm{F}-\mathrm{A}-85380$ PET has been used to observe outcome of drug treatment for the improvements of cognition in patients with mild $\mathrm{AD}$ [61]. However, no significant correlations were found between cognitive measures and nAChR simplified DV (Figure 5). These results are similar to the results reported by Kadir et al. [41] in their studies using $\left[{ }^{11} \mathrm{C}\right]$ nicotine. The relationship between cognition in $\mathrm{AD}$ and cholinergic dysfunction may be related to a number of factors, including the degree of cholinergic system (or receptor) loss, the other nAChR subtypes, or other neurochemical systems.

\section{3. $\alpha 7$ nAChR Subtype}

3.1. Relationship between $A \beta$ and $\alpha 7 n A C h R$. Of the two major subtypes of nAChRs in the CNS, $\alpha 7$ subtype has lower affinity for ACh compared to $\alpha 4 \beta 2$ subtype [62]. Accumulating evidence suggests that $\alpha 7 \mathrm{nAChR}$ plays a role in the pathophysiology of $\mathrm{AD}$. $\mathrm{A} \beta$ has picomolar affinity for $\alpha 7 \mathrm{nAChR}[63,64]$, which results in the formation of $\mathrm{A} \beta-\alpha 7$ nAChR complex. This complex is known to move intracellularly and cause neurotoxicity [63-65]. Interestingly, this neurotoxicity is not present in transgenic mouse model of $\mathrm{AD}$ overexpressing a mutated form of the human amyloid precursor protein (APP) and lacking the $\alpha 7 \mathrm{nAChR}$ [66]. Recently, Bencherif and Lippiello [67] pointed out that the $\alpha$ 7-JAK2-(NF- $\kappa \mathrm{B}$; STAT3)-Bcl2 prosurvival pathway is important for the neuroprotective role of $\alpha 7 \mathrm{nAChR}$ (Figure 6). By blocking cytosolic cytochrome C, which is released from the mitochondria via $\mathrm{A} \beta_{1--42}, \mathrm{Bcl} 2$ fully counteracts the $A \beta_{1--42}$-induced apoptosis of cells [68]. The fact that this antiapoptotic pathway is further related with ApoE4 [69], GSK-3 $\beta$-activated tau phosphorylation [70], and Wnt signaling pathways [71] denotes the critical role of $\alpha 7 \mathrm{nAChR}$ in pathophysiology of AD.

The 3xTg-AD mice [72], which are triple transgenic mice expressing APP, presinilin-1, and Tau, were shown to have an age-dependent reduction of $\alpha 7 \mathrm{nAChR}$. This reduction was limited to brain regions where intraneuronal $A \beta_{42}$ accumulation occurred [73]. The early cognitive deficits of 3xTG$\mathrm{AD}$ mice also correlate with intracellular $\mathrm{A} \beta$ accumulation, and the clearing of this $A \beta$ accumulation by immunotherapy reverses the early cognitive impairment [74].

Tg2576 transgenic mice (APPswe) dramatically reduced $\mathrm{A} \beta$ plaque expression with chronic administration of nicotine for 5.5 months [75]. It is further reported that a 10-day administration of nicotine reduced the guanidinium-soluble $\mathrm{A} \beta$ levels by 46 to $66 \%$, whereas the intracellular $\mathrm{A} \beta$ levels remained unchanged [76]. This treatment with nicotine also resulted in less glial fibrillary acidic protein- (GFAP-) immunoreactive astrocytes around the amyloid plaques and increased numbers of $\alpha 7 \mathrm{nAChR}$ in the cortex of APPswe mice [76]. Bencherif [68] points out the importance of these

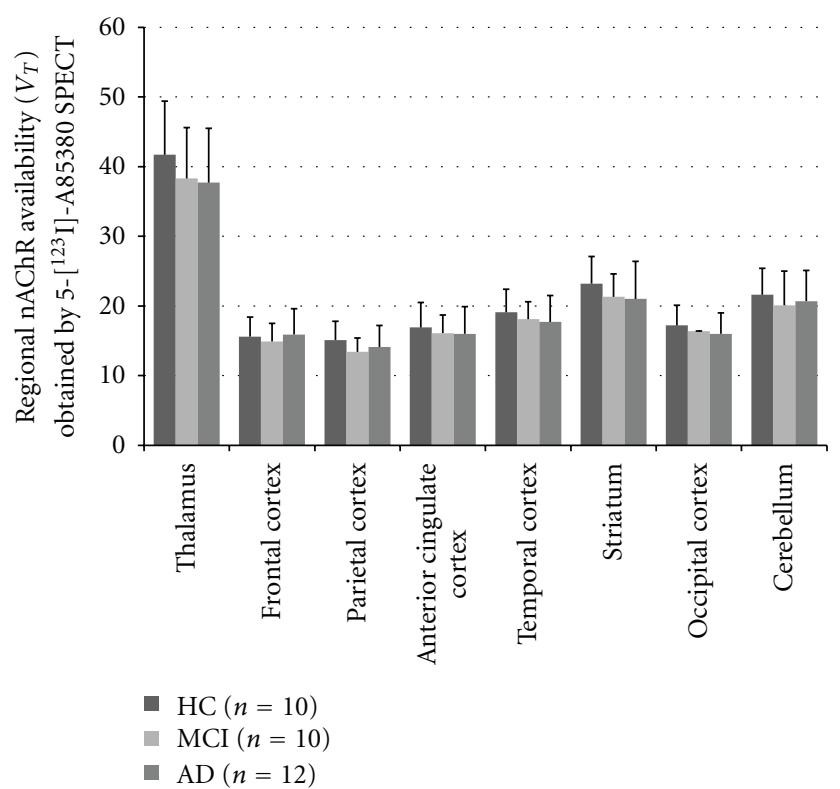

FIGURE 4: Regional $\alpha 4 \beta 2-\mathrm{nAChR}$ availability $\left(V_{T}\right)$ of 5 -[ $\left.{ }^{123} \mathrm{I}\right] \mathrm{I}-$ A85380 in age-matched healthy control (HC), mild cognitive impairment (MCI), and Alzheimer's disease (AD) groups. No significant regional differences among the subject groups for any of the 8 regions, including the 4 neocortical regions, were identified. (Data is from the paper of Mitsis et al. [58].)

data, as reduction of $A \beta$ with anti- $A \beta$ antibody treatment is reported to rapidly recover the associated neuritic dystrophy in living animals [77].

Orr-Urtreger et al. [78] generated $\alpha 7$ nAChR gene knockout (KO) mice, and the resulting $\alpha 7 \mathrm{nAChR}$ KO mice did not show any morphological central nervous system abnormalities $[78,79]$, but behavioral tests point out some cognitive deficits in KO mice, such as impaired sustained attention [80, 81], impairment in working memory [82], and impairment in performance under high attentional demand [83]. The cognitive deficits seen in APP transgenic mice worsen when $\alpha 7 \mathrm{nAChR}$ is absent at the same time [84]. These $\alpha 7 \mathrm{nAChR}$ KO APP mice showed significant reduction in hippocampal and basal forebrain choline acetyltransferase activity and loss of hippocampal neurons and markers; stereological analyses indicated more pronounced loss of hippocampal pyramidal neurons and volume loss compared with APP mice [84]. Taken all together, it is likely that $\alpha 7 \mathrm{nAChR}$ might play an important role in the process of $A \beta$ disposition which was detected in the brain of patients with AD.

3.2. Cognition and $\alpha 7 n A C h R$ Agonists. A number of $\alpha 7$ $\mathrm{nAChR}$ agonists are reported to improve recognition memory in rodents. These agonists include tropisetron [85], ABBF [86], AR-R 17779 [87], SSR180711 [88, 89], A-582941 [90], and SEN123333 [91]. In nonhuman primates, improvements in long-delay performance of delayed matching tasks are reported by $\alpha 7 \mathrm{nAChR}$ agonists GTS-21 [92] and A-582941 [93].

It is reported that nicotine inhibits $A \beta$ deposition and aggregation in the cortex and hippocampus of APP transgenic mice [94]. RNA interference experiments indicated 


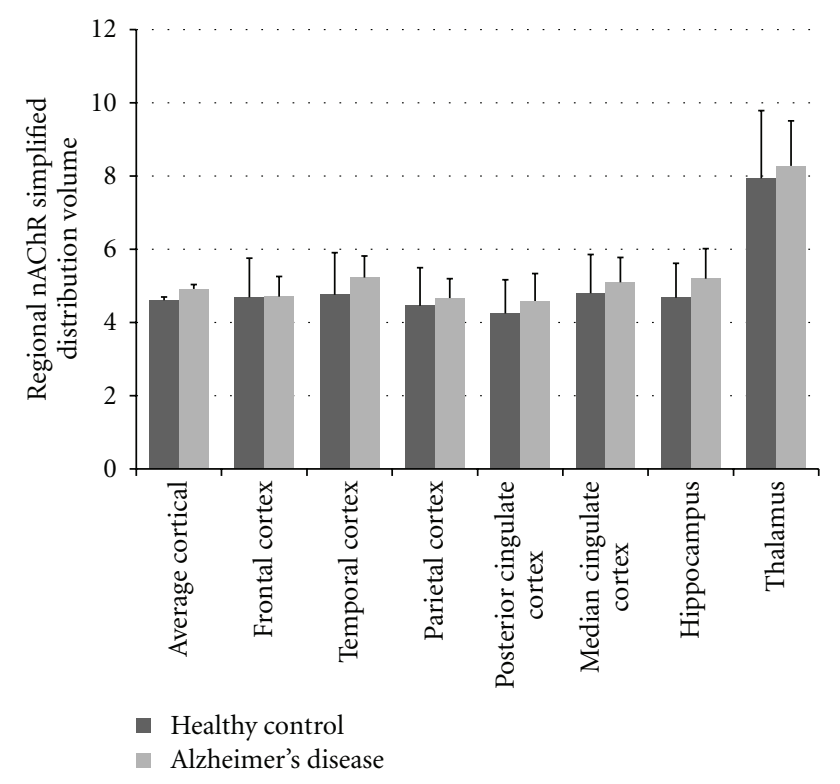

FIGURE 5: Regional nAChR simplified distribution volume (DV(s)) of 2- $\left[{ }^{18} \mathrm{~F}\right] \mathrm{F}-\mathrm{A} 85380$ in healthy control (HC) and Alzheimer's disease (AD) groups. No significant difference in $\mathrm{nAChR} \mathrm{DV(s)}$ was found between both groups. (Data is from the paper of Ellis et al. [51].)

that these nicotine-mediated effects require $\alpha 7 \mathrm{nAChR}$. In another study [70], the selective $\alpha 7 \mathrm{nAChR}$ agonist A-582941 led to increased phosphorylation of the inhibitory regulating amino acid residue Ser-9 on glycogen synthase kinase $3 \beta$ $(\mathrm{GSK} 3 \beta)$, a major kinase responsible for tau hyperphosphorylation in AD neuropathology. This was observed in mouse cingulate cortex and hippocampus and was not observed in $\alpha 7 \mathrm{nAChR}$ KO mice. S9-GSK3 $\beta$ phosphorylation was also seen in the hippocampus of Tg2576 (APP), as well as wild-type mice by steady-state exposure of A-582941. Moreover, continuous infusions of A-582941 decreased phosphorylation of tau in hippocampal CA3 Mossy fibers in a hypothermia-induced tau hyperphosphorylation mouse model and also decreased spinal motoneurons in AD double transgenic APP/tau mouse line. This group points out that $\alpha 7 \mathrm{nAChR}$ agonists may have therapeutic potential through GSK3 $\beta$ inhibition followed by reduction of tau hyperphosphorylation and further suggest that this pharmacology may have the potential to provide disease modifying benefit in the treatment of AD.

It is reported that the $\alpha 7 \mathrm{nAChR}$ agonist GTS-21 prevented $\mathrm{A} \beta_{25--35}$-induced impairment of acquisition performance and probe trail test in Morris water maze [95]. Their study showed first in vivo evidence that treatment with GTS-21 ameliorates the A $\beta$-induced deficit in spatial cognition through not only activating $\alpha 7 \mathrm{nAChR}$ but also preventing the $\mathrm{A} \beta$-impaired $\alpha 7 \mathrm{nAChR}$.

Using a novel selective $\alpha 7 \mathrm{nAChR}$ partial agonist S 24795, Wang et al. [96] showed that, in contrast to anti-AD drugs, galantamine (a cholinesterase inhibitor) and memantine (an $N$-methyl-D-aspartate (NMDA) receptor antagonist), S 24795 reduced or limited $\mathrm{A} \beta_{42}-\alpha 7 \mathrm{nAChR}$ association,
$\mathrm{A} \beta_{42}$-induced tau phosphorylation, $\mathrm{A} \beta_{42}$ accumulations, and $\mathrm{A} \beta_{42}$-mediated inhibition of $\alpha 7 \mathrm{nAChR} \mathrm{Ca}^{2+}$ influx in rodent brain [96]. S 24795 more importantly restored $\alpha 7$ nAChR functional deficits which had resulted from continued exposure to exogenous $\mathrm{A} \beta_{42}$.

Taken all together, $\alpha 7 \mathrm{nAChR}$ is one of the therapeutic targets for $\mathrm{AD}[97,98]$.

3.3. Postmortem Studies of $\alpha 7 n A C h R$ in the Brain of Patients with $A D$. In the postmortem brain of patients with $\mathrm{AD}$, decline of $\alpha 7 \mathrm{nAChR}$ appears early in the disease and was associated with the progression of cognitive deficits [99101]. Although the protein levels are reduced in the cortex and hippocampus of $\mathrm{AD}$ patients $[15,19,32,100,102]$, contradictions arise at the level of gene transcription. For example, levels of $\alpha 7 \mathrm{nAChR}$ protein were reduced by $36 \%$ in the hippocampus of $\mathrm{AD}$ patients [15], but $\alpha 7 \mathrm{nAChR}$ mRNA expression is increased by 65\% [18]. Furthermore, no differences in $\left[{ }^{125} \mathrm{I}\right] \alpha$-bungarotoxin binding were found in the frontal cortex of $\mathrm{AD}$ patients [103] and negative reduction of the $\alpha 7 \mathrm{nAChR}$ protein levels [104].

3.4. Imaging of $\alpha 7 n A C h R$ in the Brain. Given the role of $\alpha 7 \mathrm{nAChR}$ in the pathogenesis of $\mathrm{AD}$, it is of great interest to study $\alpha 7 \mathrm{nAChR}$ in the living human brain using PET/SPECT. Much effort has been devoted to visualize $\alpha 7$ $\mathrm{nAChR}$ in the brain by PET/SPECT, but the development of a radioligand that depicts $\alpha 7 \mathrm{nAChR}$ specifically has been problematic due to its relatively low amount in the brain [105-108]. Generally, $\alpha$-bungarotoxin and MLA are well known as specific $\alpha 7 \mathrm{nAChR}$ antagonists. However, due to their large molecular weights, they have difficulty passing through the blood-brain barrier which makes them unfavorable for radioligands [109-111]. Consequently, a number of radioligands for $\alpha 7 \mathrm{nAChR}$ are being developed and evaluated as PET/SPECT radioligand. However, all radioligands except $\left[{ }^{11} \mathrm{C}\right] \mathrm{CHIBA}-1001$ were unsuccessful [112].

3.5. $\left[{ }^{11}\right.$ C]CHIBA-1001 as a Novel PET Ligand for $\alpha 7 n A C h R$. We developed a novel PET ligand, 4- $\left[{ }^{11} \mathrm{C}\right]$ methylphenyl 1,4diazabicyclo[3.2.2.]nonane-4-carboxylate $\quad\left(\left[{ }^{11} \mathrm{C}\right] \mathrm{CHIBA}-\right.$ 1001) (Figure 7). A PET study using conscious monkeys demonstrated that the distribution of radioactivity in the brain regions after intravenous administration of $\left[{ }^{11} \mathrm{C}\right] \mathrm{CHIBA}-1001$ was blocked by pretreatment with the selective $\alpha 7 \mathrm{nAChR}$ agonist SSR180711 (5.0 mg/kg), but not the selective $\alpha 4 \beta 2 \mathrm{nAChR}$ agonist A85380 $(1.0 \mathrm{mg} / \mathrm{kg})$ [89]. In addition, we reported that the order of drugs for the inhibition of $\left[{ }^{3} \mathrm{H}\right] \mathrm{CHIBA}-1001$ binding to rat brain membranes was similar to $\alpha 7 \mathrm{nAChR}$ pharmacological profiles [113]. We also reported a preliminary PET study of $\left[{ }^{11} \mathrm{C}\right] \mathrm{CHIBA}-1001$ in a healthy human $[114,115]$. Very recently, we reported that $\left[{ }^{125} \mathrm{I}\right] \mathrm{CHIBA}-1006$, an iodine derivative of SSR180711, has a high affinity for $\alpha 7 \mathrm{nAChR}$ as compared with CHIBA-1001 [116]. Considering the good brain permeability of derivatives (e.g., SSR180711 and CHIBA-1001) of CHIBA-1006, it would be of great interest 


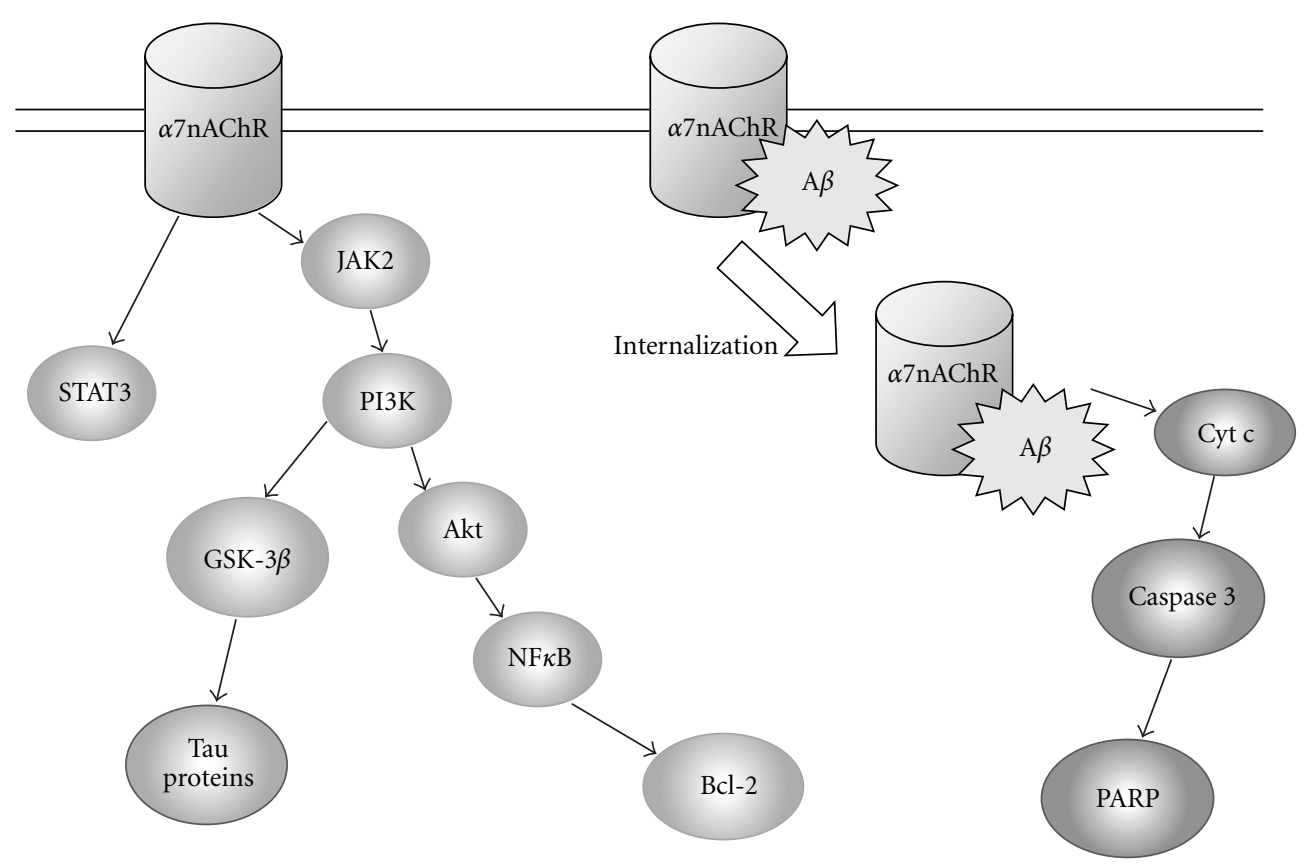

FIGURE 6: Schematic representation of neuroprotective role of $\alpha 7 \mathrm{nAChR}$.<smiles>Cc1ccc(OC(=O)N2CCN3CCC2CC3)cc1</smiles>

$\left.{ }^{[1} \mathrm{C}\right] \mathrm{CHIBA} 1001$

Figure 7: Chemical structure of $\left[{ }^{11} \mathrm{C}\right] \mathrm{CHIBA}-1001$.

to examine whether $\left[{ }^{123} \mathrm{I}\right] \mathrm{CHIBA}-1006$ and $\left[{ }^{124} \mathrm{I}\right] \mathrm{CHIBA}-$ 1006 are suitable radioligands for in vivo labeling of $\alpha 7$ nAChRs in the brain using SPECT and PET, respectively [116].

At present, $\left[{ }^{11} \mathrm{C}\right] \mathrm{CHIBA}-1001$ is the only PET ligand which can be available for in vivo study of $\alpha 7$ nAChRs in intact human brain [114]. PET studies of $\left[{ }^{11} \mathrm{C}\right]$ CHIBA- 1001 in patients with AD are currently underway with $\left[{ }^{11} \mathrm{C}\right]$ Pittsburgh compound $\mathrm{D}\left(\left[{ }^{11} \mathrm{C}\right] \mathrm{PiB}\right)$-PET and $\left[{ }^{18} \mathrm{~F}\right]$ fluorodeoxyglucose $\left(\left[{ }^{18} \mathrm{~F}\right] \mathrm{FDG}\right)$-PET. This study aims to evaluate the relationship between the distribution of $\alpha 7 \mathrm{nAChR}$ (assessed by $\left[{ }^{11} \mathrm{C}\right] \mathrm{CHIBA}-1001$ ) and $\mathrm{A} \beta$ disposition (assessed by $\left[{ }^{11} \mathrm{C}\right] \mathrm{PiB}$ ), while estimating the stage and cognitive levels (assessed by $\left[{ }^{18} \mathrm{~F}\right] \mathrm{FDG}-\mathrm{PET}$ and neuropsychological examinations) for each $\mathrm{AD}$ patient.

\section{Conclusions}

Considering the importance of early prevention of onset of $\mathrm{AD}$, it is very important to detect alternations in nAChRs at the presymptomatic stage of $\mathrm{AD}$. In patients with $\mathrm{MCI}$, the early detection and early therapeutic intervention would be beneficial. Therefore, brain imaging of nAChRs using PET and SPECT will be a powerful tool to study the mechanisms underlying pathological brain processes of cognitive disturbances in these patients. Currently, some PET and SPECT ligands for both subtypes $(\alpha 4 \beta 2 \mathrm{nAChR}$ and $\alpha 7$ $\mathrm{nAChR}$ ) have been used to investigate the changes in receptor densities and functions of patients with AD. Gaining a better understanding of the role of nAChRs in the pathophysiology of $\mathrm{AD}$ is expected to provide new perspectives for treating this disorder.

\section{Conflict of Interests}

The authors have no conflict of interests.

\section{Abbreviations}

AD: Alzheimer's disease

DV: Distribution volume

GFAP: Glial fibrillary acidic protein

LTP: Long-term potentiation

nAChR: Nicotinic acetylcholine receptor

PET: Positron emission tomography

SPECT: Single-photon emission tomography.

\section{Acknowledgments}

This study was supported in part by a grant from the Program for Promotion of Fundamental Studies in Health Sciences of the National Institute of Biomedical Innovation of Japan (Grant ID: 06-46, to K. Hashimoto). The authors would like to thank their collaborators who are listed as the coauthors of their papers in the reference list. 


\section{References}

[1] D. A. Evans, H. H. Funkenstein, M. S. Albert et al., "Prevalence of Alzheimer's disease in a community population of older persons. Higher than previously reported," Journal of the American Medical Association, vol. 262, no. 18, pp. 25512556, 1989.

[2] R. Brookmeyer, E. Johnson, K. Ziegler-Graham, and H. M. Arrighi, "Forecasting the global burden of Alzheimer's disease," Alzheimer's and Dementia, vol. 3, no. 3, pp. 186-191, 2007.

[3] J. N. Octave, "The amyloid peptide and its precursor in Alzheimer's disease," Reviews in the Neurosciences, vol. 6, no. 4, pp. 287-316, 1995.

[4] E. Grober, C. B. Hall, R. B. Lipton, A. B. Zonderman, S. M. Resnick, and C. Kawas, "Memory impairment, executive dysfunction, and intellectual decline in preclinical Alzheimer's disease," Journal of the International Neuropsychological Society, vol. 14, no. 2, pp. 266-278, 2008.

[5] C. M. van Duijn and A. Hofman, "Relation between nicotine intake and Alzheimer's disease," British Medical Journal, vol. 302, no. 6791, pp. 1491-1494, 1991.

[6] A. B. Graves, C. M. van Duijn, V. Chandra et al., "Alcohol and tobacco consumption as risk factors for Alzheimer's disease: a collaborative re-analysis of case-control studies," International Journal of Epidemiology, vol. 20, supplement 2, pp. S48-S57, 1991.

[7] J. M. Rusted and S. Trawley, "Comparable effects of nicotine in smokers and nonsmokers on a prospective memory task," Neuropsychopharmacology, vol. 31, no. 7, pp. 1545-1549, 2006.

[8] G. E. Swan and C. N. Lessov-Schlaggar, "The effects of tobacco smoke and nicotine on cognition and the brain," Neuropsychology Review, vol. 17, no. 3, pp. 259-273, 2007.

[9] R. Peters, R. Poulter, J. Warner, N. Beckett, L. Burch, and C. Bulpitt, "Smoking, dementia and cognitive decline in the elderly, a systematic review," BMC Geriatrics, vol. 8, article 36, 2008.

[10] J. K. Cataldo, J. J. Prochaska, and S. A. Glantz, "Cigarette smoking is a risk factor for Alzheimer's disease: an analysis controlling for tobacco industry affiliation," Journal of Alzheimer's Disease, vol. 19, no. 2, pp. 465-480, 2010.

[11] J. K. Cataldo and S. A. Glantz, "Smoking cessation and Alzheimer's disease: facts, fallacies and promise," Expert Review of Neurotherapeutics, vol. 10, no. 5, pp. 629-631, 2010.

[12] C. Gotti, M. Zoli, and F. Clementi, "Brain nicotinic acetylcholine receptors: native subtypes and their relevance," Trends in Pharmacological Sciences, vol. 27, no. 9, pp. 482491, 2006.

[13] D. Paterson and A. Nordberg, "Neuronal nicotinic receptors in the human brain," Progress in Neurobiology, vol. 61, no. 1, pp. 75-111, 2000.

[14] J. A. Dani and D. Bertrand, "Nicotinic acetylcholine receptors and nicotinic cholinergic mechanisms of the central nervous system," Annual Review of Pharmacology and Toxicology, vol. 47, pp. 699-729, 2007.

[15] Z. Z. Guan, X. Zhang, R. Ravid, and A. Nordberg, "Decreased protein levels of nicotinic receptor subunits in the hippocampus and temporal cortex of patients with Alzheimer's disease," Journal of Neurochemistry, vol. 74, no. 1, pp. 237$243,2000$.
[16] X. A. Perez, T. Bordia, J. M. McIntosh, and M. Quik, “ $\alpha 6 \beta 2 *$ and $\alpha 4 \beta 2^{*}$ nicotinic receptors both regulate dopamine signaling with increased nigrostriatal damage: relevance to Parkinson's disease," Molecular Pharmacology, vol. 78, no. 5, pp. 971-980, 2010.

[17] E. K. Perry, C. M. Morris, J. A. Court et al., "Alteration in nicotine binding sites in Parkinson's disease, Lewy body dementia and Alzheimer's disease: possible index of early neuropathology," Neuroscience, vol. 64, no. 2, pp. 385-395, 1995.

[18] E. Hellström-Lindahl, M. Mousavi, X. Zhang, R. Ravid, and A. Nordberg, "Regional distribution of nicotinic receptor subunit mRNAs in human brain: comparison between Alzheimer and normal brain," Molecular Brain Research, vol. 66, no. 1-2, pp. 94-103, 1999.

[19] L. Burghaus, U. Schütz, U. Krempel et al., "Quantitative assessment of nicotinic acetylcholine receptor proteins in the cerebral cortex of Alzheimer patients," Molecular Brain Research, vol. 76, no. 2, pp. 385-388, 2000.

[20] B. A. Yankner, L. K. Duffy, and D. A. Kirschner, "Neurotrophic and neurotoxic effects of amyloid $\beta$ protein: reversal by tachykinin neuropeptides," Science, vol. 250, no. 4978, pp. 279-282, 1990.

[21] N. W. Kowall, M. F. Beal, J. Busciglio, L. K. Duffy, and B. A. Yankner, "An in vivo model for the neurodegenerative effects of $\beta$ amyloid and protection by substance P," Proceedings of the National Academy of Sciences of the United States of America, vol. 88, no. 16, pp. 7247-7251, 1991.

[22] T. Kihara, S. Shimohama, M. Urushitani et al., "Stimulation of $\alpha 4 \beta 2$ nicotinic acetylcholine receptors inhibits $\beta$ - amyloid toxicity," Brain Research, vol. 792, no. 2, pp. 331-334, 1998.

[23] W. Fu and J. H. Jhamandas, " $\beta$-amyloid peptide activates non- $\alpha 7$ nicotinic acetylcholine receptors in rat basal forebrain neurons," Journal of Neurophysiology, vol. 90, no. 5, pp. 3130-3136, 2003.

[24] M. N. Wu, Y. X. He, F. Guo, and J. S. Qi, “ $\alpha 4 \beta 2$ nicotinic acetylcholine receptors are required for the amyloid $\beta$ protein-induced suppression of long-term potentiation in rat hippocampal CA1 region in vivo," Brain Research Bulletin, vol. 77, no. 2-3, pp. 84-90, 2008.

[25] P. A. Newhouse, A. Potter, and A. Singh, "Effects of nicotinic stimulation on cognitive performance," Current Opinion in Pharmacology, vol. 4, no. 1, pp. 36-46, 2004.

[26] J. Loughead, R. Ray, E. P. Wileyto et al., "Effects of the $\alpha 4 \beta 2$ partial agonist varenicline on brain activity and working memory in abstinent smokers," Biological Psychiatry, vol. 67, no. 8, pp. 715-721, 2010.

[27] D. D. Flynn and D. C. Mash, "Characterization of L$\left[{ }^{3} \mathrm{H}\right]$ nicotine binding in human cerebral cortex: comparison between Alzheimer's disease and the normal," Journal of Neurochemistry, vol. 47, no. 6, pp. 1948-1954, 1986.

[28] P. J. Whitehouse, A. M. Martino, P. G. Antuono et al., "Nicotinic acetylcholine binding sites in Alzheimer's disease," Brain Research, vol. 371, no. 1, pp. 146-151, 1986.

[29] P. J. Whitehouse, A. M. Martino, M. V. Wagster et al., "Reductions in $\left[{ }^{3} \mathrm{H}\right]$ nicotinic acetylcholine binding in Alzheimer's disease and Parkinson's disease: an autoradiographic study," Neurology, vol. 38, no. 5, pp. 720-723, 1988.

[30] U. Warpman and A. Nordberg, "Epibatidine and ABT 418 reveal selective losses of $\alpha 4 \beta 2$ nicotinic receptors in Alzheimer brains," NeuroReport, vol. 6, no. 17, pp. 24192423, 1995. 
[31] A. Marutle, U. Warpman, N. Bogdanovic, L. Lannfelt, and A. Nordberg, "Neuronal nicotinic receptor deficits in Alzheimer patients with the Swedish amyloid precursor protein 670/671 mutation," Journal of Neurochemistry, vol. 72, no. 3, pp. 1161-1169, 1999.

[32] A. Wevers, L. Burghaus, N. Moser et al., "Expression of nicotinic acetylcholine receptors in Alzheimer's disease: postmortem investigations and experimental approaches," Behavioural Brain Research, vol. 113, no. 1-2, pp. 207-215, 2000.

[33] J. D. Gallezot, M. Bottlaender, M. C. Grégoire et al., “in vivo imaging of human cerebral nicotinic acetylcholine receptors with $2-{ }^{18}$ F-fluoro-A-85380 and PET," Journal of Nuclear Medicine, vol. 46, no. 2, pp. 240-247, 2005.

[34] A. L. Brody, M. A. Mandelkern, E. D. London et al., "Cigarette smoking saturates brain $\alpha 4 \beta 2$ nicotinic acetylcholine receptors," Archives of General Psychiatry, vol. 63, no. 8, pp. 907915, 2006.

[35] A. Kadir, O. Almkvist, A. Wall, B. Långström, and A. Nordberg, "PET imaging of cortical C-nicotine binding correlates with the cognitive function of attention in Alzheimer's disease," Psychopharmacology, vol. 188, no. 4, pp. 509-520, 2006.

[36] M. Maziere, D. Comar, C. Marazano, and G. Berger, "Nicotine ${ }^{11} \mathrm{C}$ : synthesis and distribution kinetics in animals," European Journal of Nuclear Medicine, vol. 1, no. 4, pp. 255$258,1976$.

[37] C. Halldin, K. Nagren, C. G. Swahn, B. Langstrom, and H. Nyback, " $(S)$ - and $(R)-\left[{ }^{11} \mathrm{C}\right]$ nicotine and the metabolite $(R / S)-\left[{ }^{11} \mathrm{C}\right]$ cotinine. Preparation, metabolite studies and in vivo distribution in the human brain using PET," International Journal of Radiation Applications and Instrumentation $B$, vol. 19, no. 8, pp. 871-880, 1992.

[38] H. Nyback, A. Nordberg, B. Langstrom et al., "Attempts to visualize nicotinic receptors in the brain of monkey and man by positron emission tomography," Progress in Brain Research, vol. 79, pp. 313-319, 1989.

[39] A. Nordberg, L. Nilsson-Hakansson, A. Adem et al., "The role of nicotinic receptors in the pathophysiology of Alzheimer's disease," Progress in Brain Research, vol. 79, pp. 353-362, 1989.

[40] A. Nordberg, H. Lundqvist, P. Hartvig, A. Lilja, and B. Langstrom, "Kinetic analysis of regional $(\mathrm{S})(-)^{11} \mathrm{C}$-nicotine binding in normal and Alzheimer brains_-in vivo assessment using positron emission tomography," Alzheimer Disease and Associated Disorders, vol. 9, no. 1, pp. 21-27, 1995.

[41] A. Kadir, T. Darreh-Shori, O. Almkvist et al., "PET imaging of the in vivo brain acetylcholinesterase activity and nicotine binding in galantamine-treated patients with AD," Neurobiology of Aging, vol. 29, no. 8, pp. 1204-1217, 2008.

[42] A. Nordberg, H. Lundqvist, P. Hartvig et al., "Imaging of nicotinic and muscarinic receptors in Alzheimer's disease: effect of tacrine treatment," Dementia and Geriatric Cognitive Disorders, vol. 8, no. 2, pp. 78-84, 1997.

[43] F. Grunwald, H. J. Biersack, W. Kuschinsky, D. Sorger, I. Kampfer, and W. H. Knapp, "Nicotine receptor mapping," European Journal of Nuclear Medicine, vol. 23, no. 8, pp. 1012-1014, 1996.

[44] J. P. Sullivan, D. Donnelly-Roberts, C. A. Briggs et al., "A-85380 [3-(2(S)-azetidinylmethoxy) pyridine]: in vitro pharmacological properties of a novel, high affinity $\alpha 4 \beta 2$ nicotinic acetylcholine receptor ligand," Neuropharmacology, vol. 35, no. 6, pp. 725-734, 1996.
[45] L. E. Rueter, M. D. Meyer, and M. W. Decker, "Spinal mechanisms underlying A-85380-induced effects on acute thermal pain," Brain Research, vol. 872, no. 1-2, pp. 93-101, 2000.

[46] M. J. Buckley, C. Surowy, M. Meyer, and P. Curzon, "Mechanism of action of A-85380 in an animal model of depression," Progress in Neuro-Psychopharmacology and Biological Psychiatry, vol. 28, no. 4, pp. 723-730, 2004.

[47] L. E. Rueter, D. L. Donnelly-Roberts, P. Curzon, C. A. Briggs, D. J. Anderson, and R. S. Bitner, "A-85380: a pharmacological probe for the preclinical and clinical investigation of the $\alpha \beta$ neuronal nicotinic acetylcholine receptor," CNS Drug Reviews, vol. 12, no. 2, pp. 100-112, 2006.

[48] A. G. Mukhin, D. Gündisch, A. G. Horti et al., "5-iodoa-85380, an $\alpha 4 \beta 2$ subtype-selective ligand for nicotinic acetylcholine receptors," Molecular Pharmacology, vol. 57, no. 3, pp. 642-649, 2000.

[49] S. I. Chefer, E. D. London, A. O. Koren et al., "Graphical analysis of $2-\left[{ }^{18} \mathrm{~F}\right] \mathrm{FA}$ binding to nicotinic acetylcholine receptors in rhesus monkey brain," Synapse, vol. 48, no. 1, pp. 25-34, 2003.

[50] A. S. Kimes, A. G. Horti, E. D. London et al., "2- $\left[{ }^{18} \mathrm{~F}\right] \mathrm{F}-$ A-85380: PET imaging of brain nicotinic acetylcholine receptors and whole body distribution in humans," FASEB Journal, vol. 17, no. 10, pp. 1331-1333, 2003.

[51] J. R. Ellis, V. L. Villemagne, P. J. Nathan et al., "Relationship between nicotinic receptors and cognitive function in early Alzheimer's disease: a 2-[ $\left.{ }^{18} \mathrm{~F}\right]$ fluoro-A-85380 PET study," Neurobiology of Learning and Memory, vol. 90, no. 2, pp. 404412, 2008.

[52] M. Fujita, M. Ichise, C. H. van Dyck et al., "Quantification of nicotinic acetylcholine receptors in human brain using [ ${ }^{123}$ I] 5-I-A-85380 SPET," European Journal of Nuclear Medicine and Molecular Imaging, vol. 30, no. 12, pp. 16201629, 2003.

[53] E. M. Mitsis, K. P. Cosgrove, J. K. Staley et al., "Age-related decline in nicotinic receptor availability with [ $\left.{ }^{123} \mathrm{I}\right] 5-\mathrm{IA}-$ 85380 SPECT," Neurobiology of Aging, vol. 30, no. 9, pp. 1490-1497, 2009.

[54] K. P. Cosgrove, J. Batis, F. Bois et al., “ $\beta 2$-nicotinic acetylcholine receptor availability during acute and prolonged abstinence from tobacco smoking," Archives of General Psychiatry, vol. 66, no. 6, pp. 666-676, 2009.

[55] A. L. Brody, M. A. Mandelkern, M. R. Costello et al., "Brain nicotinic acetylcholine receptor occupancy: effect of smoking a denicotinized cigarette," International Journal of Neuropsychopharmacology, vol. 12, no. 3, pp. 305-316, 2009.

[56] O. Sabri, K. Kendziorra, H. Wolf, H. J. Gertz, and P. Brust, "Acetylcholine receptors in dementia and mild cognitive impairment," European Journal of Nuclear Medicine and Molecular Imaging, vol. 35, no. 1, pp. S30-S45, 2008.

[57] K. Kendziorra, H. Wolf, P. M. Meyer et al., "Decreased cerebral $\alpha 4 \beta 2 *$ nicotinic acetylcholine receptor availability in patients with mild cognitive impairment and Alzheimer's disease assessed with positron emission tomography," European Journal of Nuclear Medicine and Molecular Imaging. In press.

[58] E. M. Mitsis, K. M. Reech, F. Bois et al., "123 I-5-IA- 85380 SPECT imaging of nicotinic receptors in Alzheimer disease and mild cognitive impairment," Journal of Nuclear Medicine, vol. 50, no. 9, pp. 1455-1463, 2009. 
[59] J. T. O’Brien, S. J. Colloby, S. Pakrasi et al., “ $\alpha 4 \beta 2$ nicotinic receptor status in Alzheimer's disease using I-5IA-85380 single-photon-emission computed tomography," Journal of Neurology, Neurosurgery and Psychiatry, vol. 78, no. 4, pp. 356-361, 2007.

[60] S. J. Colloby, E. K. Perry, S. Pakrasi et al., "Nicotinic ${ }^{123}$ I-5IA85380 single photon emission computed tomography as a predictor of cognitive progression in alzheimer's disease and dementia with lewy Bodies," American Journal of Geriatric Psychiatry, vol. 18, no. 1, pp. 86-90, 2010.

[61] J. R. Ellis, P. J. Nathan, V. L. Villemagne et al., "Galantamineinduced improvements in cognitive function are not related to alterations in $\alpha 4 \beta 2$ nicotinic receptors in early Alzheimer's disease as measured in vivo by 2 - $\left[{ }^{18} \mathrm{~F}\right]$ Fluoro-A- 85380 PET," Psychopharmacology, vol. 202, no. 1-3, pp. 79-91, 2009.

[62] P. B. S. Clarke, "The fall and rise of neuronal $\alpha$-bungarotoxin binding proteins," Trends in Pharmacological Sciences, vol. 13, no. 11, pp. 407-413, 1992.

[63] H. Y. Wang, D. H. S. Lee, M. R. D’Andrea, P. A. Peterson, R. P. Shank, and A. B. Reitz, " $\beta$-Amyloid(1-42) binds to $\alpha 7$ nicotinic acetylcholine receptor with high affinity. Implications for Alzheimer's disease pathology," Journal of Biological Chemistry, vol. 275, no. 8, pp. 5626-5632, 2000.

[64] H. Y. Wang, D. H. S. Lee, C. B. Davis, and R. P. Shank, "Amyloid peptide $\mathrm{A} \beta(1-42)$ binds selectively and with picomolar affinity to $\alpha 7$ nicotinic acetylcholine receptors," Journal of Neurochemistry, vol. 75, no. 3, pp. 1155-1161, 2000.

[65] M. R. D’Andrea, R. G. Nagele, H. Y. Wang, P. A. Peterson, and D. H. S. Lee, "Evidence that neurones accumulating amyloid can undergo lysis to form amyloid plaques in Alzheimer's disease," Histopathology, vol. 38, no. 2, pp. 120-134, 2001.

[66] G. Dziewczapolski, C. M. Glogowski, E. Masliah, and S. F. Heinemann, "Deletion of the $\alpha 7$ nicotinic acetylcholine receptor gene improves cognitive deficits and synaptic pathology in a mouse model of Alzheimer's disease," Journal of Neuroscience, vol. 29, no. 27, pp. 8805-8815, 2009.

[67] M. Bencherif and P. M. Lippiello, “ $\alpha 7$ neuronal nicotinic receptors: the missing link to understanding Alzheimer's etiopathology?" Medical Hypotheses, vol. 74, no. 2, pp. 281285, 2010.

[68] M. Bencherif, "Neuronal nicotinic receptors as novel targets for inflammation and neuroprotection: mechanistic considerations and clinical relevance," Acta Pharmacologica Sinica, vol. 30, no. 6, pp. 702-714, 2009.

[69] D. Eddins, R. C. Klein, J. L. Yakel, and E. D. Levin, "Hippocampal infusions of apolipoprotein E peptides induce long-lasting cognitive impairment," Brain Research Bulletin, vol. 79, no. 2, pp. 111-115, 2009.

[70] R. S. Bitner, A. L. Nikkel, S. Markosyan, S. Otte, P. Puttfarcken, and M. Gopalakrishnan, "Selective $\alpha 7$ nicotinic acetylcholine receptor activation regulates glycogen synthase kinase $3 \beta$ and decreases tau phosphorylation in vivo," Brain Research, vol. 1265, no. C, pp. 65-74, 2009.

[71] G. G. Farías, A. S. Vallés, M. Colombres et al., "Wnt-7a induces presynaptic colocalization of $\alpha 7$-nicotinic acetylcholine receptors and adenomatous polyposis coli in hippocampal neurons," Journal of Neuroscience, vol. 27, no. 20, pp. 5313-5325, 2007.

[72] S. Oddo, A. Caccamo, J. D. Shepherd et al., "Triple-transgenic model of Alzheimer's disease with plaques and tangles: intracellular $\mathrm{A} \beta$ and synaptic dysfunction," Neuron, vol. 39, no. 3, pp. 409-421, 2003.
[73] S. Oddo, A. Caccamo, K. N. Green et al., "Chronic nicotine administration exacerbates tau pathology in a transgenic model of Alzheimer's disease," Proceedings of the National Academy of Sciences of the United States of America, vol. 102, no. 8, pp. 3046-3051, 2005.

[74] L. M. Billings, S. Oddo, K. N. Green, J. L. McGaugh, and F. M. LaFerla, "Intraneuronal A $\beta$ causes the onset of early Alzheimer's disease-related cognitive deficits in transgenic mice," Neuron, vol. 45, no. 5, pp. 675-688, 2005.

[75] A. Nordberg, E. Hellström-Lindahl, M. Lee et al., "Chronic nicotine treatment reduces $\beta$-amyloidosis in the brain of a mouse model of Alzheimer's disease (APPsw)," Journal of Neurochemistry, vol. 81, no. 3, pp. 655-658, 2002.

[76] C. Unger, M. M. Svedberg, W. F. Yu, M. M. Hedberg, and A. Nordberg, "Effect of subchronic treatment of memantine, galantamine, and nicotine in the brain of Tg2576 (APPswe) transgenic mice," Journal of Pharmacology and Experimental Therapeutics, vol. 317, no. 1, pp. 30-36, 2006.

[77] R. P. Brendza, B. J. Bacskai, J. R. Cirrito et al., "Anti-A $\beta$ antibody treatment promotes the rapid recovery of amyloidassociated neuritic dystrophy in PDAPP transgenic mice," Journal of Clinical Investigation, vol. 115, no. 2, pp. 428-433, 2005.

[78] A. Orr-Urtreger, F. M. Goldner, M. Saeki et al., "Mice deficient in the $\alpha 7$ neuronal nicotinic acetylcholine receptor lack $\alpha$-bungarotoxin binding sites and hippocampal fast nicotinic currents," Journal of Neuroscience, vol. 17, no. 23, pp. 9165-9171, 1997.

[79] R. Paylor, M. Nguyen, J. N. Crawley, J. Patrick, A. Beaudet, and A. Orr-Urtreger, " $\alpha 7$ nicotinic receptor subunits are not necessary for hippocampal- dependent learning or sensorimotor gating: a behavioral characterization of Acra7deficient mice," Learning and Memory, vol. 5, no. 4-5, pp. 302-316, 1998.

[80] E. Hoyle, R. F. Genn, C. Fernandes, and I. P. Stolerman, "Impaired performance of $\alpha 7$ nicotinic receptor knockout mice in the five-choice serial reaction time task," Psychopharmacology, vol. 189, no. 2, pp. 211-223, 2006.

[81] J. W. Young, N. Crawford, J. S. Kelly et al., "Impaired attention is central to the cognitive deficits observed in alpha 7 deficient mice," European Neuropsychopharmacology, vol. 17, no. 2, pp. 145-155, 2007.

[82] C. Fernandes, E. Hoyle, E. Dempster, L. C. Schalkwyk, and D. A. Collier, "Performance deficit of $\alpha 7$ nicotinic receptor knockout mice in a delayed matching-to-place task suggests a mild impairment of working/episodic-like memory," Genes, Brain and Behavior, vol. 5, no. 6, pp. 433-440, 2006.

[83] J. J. Keller, A. B. Keller, B. J. Bowers, and J. M. Wehner, "Performance of $\alpha 7$ nicotinic receptor null mutants is impaired in appetitive learning measured in a signaled nose poke task," Behavioural Brain Research, vol. 162, no. 1, pp. 143-152, 2005.

[84] C. M. Hernandez, R. Kayed, H. Zheng, J. D. Sweatt, and K. T. Dineley, "Loss of $\alpha 7$ nicotinic receptors enhances $\beta$-amyloid oligomer accumulation, exacerbating early-stage cognitive decline and septohippocampal pathology in a mouse model of Alzheimer's disease," Journal of Neuroscience, vol. 30, no. 7, pp. 2442-2453, 2010.

[85] K. Hashimoto, Y. Fujita, T. Ishima, H. Hagiwara, and M. Iyo, "Phencyclidine-induced cognitive deficits in mice are improved by subsequent subchronic administration of tropisetron: role of $\alpha 7$ nicotinic receptors," European Journal of Pharmacology, vol. 553, no. 1-3, pp. 191-195, 2006. 
[86] F. G. Boess, J. de Vry, C. Erb et al., "The novel $\alpha 7$ nicotinic acetylcholine receptor agonist $\mathrm{N}-[(3 R)-1$ azabicyclo[2.2.2] oct-3-yl]-7-[2-(methoxy)phenyl]-1benzofuran-2- carboxamide improves working and recognition memory in rodents," Journal of Pharmacology and Experimental Therapeutics, vol. 321, no. 2, pp. 716-725, 2007.

[87] M. van Kampen, K. Selbach, R. Schneider, E. Schiegel, F. Boess, and R. Schreiber, "AR-R 17779 improves social recognition in rats by activation of nicotinic $\alpha 7$ receptors," Psychopharmacology, vol. 172, no. 4, pp. 375-383, 2004.

[88] P. Pichat, O. E. Bergis, J. P. Terranova et al., "SSR180711, a novel selective $\alpha 7$ nicotinic receptor partial agonist: (II) efficacy in experimental models predictive of activity against cognitive symptoms of schizophrenia," Neuropsychopharmacology, vol. 32, no. 1, pp. 17-34, 2007.

[89] K. Hashimoto, S. Nishiyama, H. Ohba et al., " $\left[{ }^{11} \mathrm{C}\right] \mathrm{CHIBA}-$ 1001 as a novel PET ligand for $\alpha 7$ nicotinic receptors in the brain: a PET study in conscious monkeys," PLoS ONE, vol. 3, no. 9, article e3231, 2008.

[90] K. R. Tietje, D. J. Anderson, R. S. Bitner et al., "Preclinical characterization of A-582941: a novel $\alpha 7$ neuronal nicotinic receptor agonist with broad spectrum cognition-enhancing properties," CNS Neuroscience and Therapeutics, vol. 14, no. 1, pp. 65-82, 2008.

[91] R. Roncarati, C. Scali, T. A. Comery et al., "Procognitive and neuroprotective activity of a novel $\alpha 7$ nicotinic acetylcholine receptor agonist for treatment of neurodegenerative and cognitive disorders," Journal of Pharmacology and Experimental Therapeutics, vol. 329, no. 2, pp. 459-468, 2009.

[92] C. A. Briggs, D. J. Anderson, J. D. Brioni et al., "Functional characterization of the novel neuronal nicotinic acetylcholine receptor ligand GTS-21 in vitro and in vivo," Pharmacology Biochemistry and Behavior, vol. 57, no. 1-2, pp. 231-241, 1997.

[93] J. J. Buccafusco, A. V. Terry Jr., M. W. Decker, and M. Gopalakrishnan, "Profile of nicotinic acetylcholine receptor agonists ABT-594 and A-582941, with differential subtype selectivity, on delayed matching accuracy by young monkeys," Biochemical Pharmacology, vol. 74, no. 8, pp. 1202 1211, 2007.

[94] Q. Liu, J. Zhang, H. Zhu, C. Qin, Q. Chen, and B. Zhao, "Dissecting the signaling pathway of nicotine-mediated neuroprotection in a mouse Alzheimer disease model," FASEB Journal, vol. 21, no. 1, pp. 61-73, 2007.

[95] L. Chen, H. Wang, Z. Zhang et al., "DMXB (GTS-21) ameliorates the cognitive deficits in beta amyloid ${ }_{25-35}$-injected mice through preventing the dysfunction of $\alpha 7$ nicotinic receptor," Journal of Neuroscience Research, vol. 88, no. 8, pp. 17841794, 2010.

[96] H. Y. Wang, K. Bakshi, C. Shen, M. Frankfurt, C. TrocméThibierge, and P. Morain, "S 24795 limits $\beta$-amyloid$\alpha 7$ nicotinic receptor interaction and reduces Alzheimer's disease-like pathologies," Biological Psychiatry, vol. 67, no. 6, pp. 522-530, 2010.

[97] K. Hashimoto and M. Iyo, "Amyloid cascade hypothesis of Alzheimer's disease and $\alpha 7$ nicotinic receptor," Nihon Shinkei Seishin Yakurigaku Zasshi, vol. 22, no. 2, pp. 9-53, 2002.

[98] J. Toyohara and K. Hashimoto, “ $\alpha 7$ nicotinic receptor agonists: potential therapeutic drugs for treatment of cognitive impairments in schizophrenia and Alzheimer's disease," Open Medicinal Chemistry Journal, vol. 4, pp. 37-56, 2010.
[99] A. Nordberg, "Human nicotinic receptors-their role in aging and dementia," Neurochemistry International, vol. 25, no. 1, pp. 93-97, 1994.

[100] A. Nordberg, "Nicotinic receptor abnormalities of Alzheimer's disease: therapeutic implications," Biological Psychiatry, vol. 49, no. 3, pp. 200-210, 2001.

[101] P. J. Whitehouse and R. N. Kalaria, "Nicotinic receptors and neurodegenerative dementing diseases: basic research and clinical implications," Alzheimer Disease and Associated Disorders, vol. 9, supplement 2, pp. 3-5, 1995.

[102] C. M. Martin-Ruiz, J. A. Court, E. Molnar et al., " $\alpha 4$ but not $\alpha 3$ and $\alpha 7$ nicotinic acetylcholine receptor subunits are lost from the temporal cortex in Alzheimer's disease," Journal of Neurochemistry, vol. 73, no. 4, pp. 1635-1640, 1999.

[103] P. Davies and S. Feisullin, "Postmortem stability of $\alpha$ bungarotoxin binding sites in mouse and human brain," Brain Research, vol. 216, no. 2, pp. 449-454, 1981.

[104] E. Engidawork, T. Gulesserian, N. Balic, N. Cairns, and G. Lubec, "Changes in nicotinic acetylcholine receptor subunits expression in brain of patients with Down syndrome and Alzheimer's disease," Journal of Neural Transmission, Supplement, no. 61, pp. 211-222, 2001.

[105] L. Falk, A. Nordberg, A. Seiger, A. Kjaeldgaard, and E. Hellström-Lindahl, "Higher expression of $\alpha 7$ nicotinic acetylcholine receptors in human fetal compared to adult brain," Developmental Brain Research, vol. 142, no. 2, pp. 151-160, 2003.

[106] A. Marutle, X. Zhang, J. Court et al., "Laminar distribution of nicotinic receptor subtypes in cortical regions in schizophrenia," Journal of Chemical Neuroanatomy, vol. 22, no. 1-2, pp. 115-126, 2001.

[107] J. A. Court, E. K. Perry, D. Spurden et al., "The role of the cholinergic system in the development of the human cerebellum," Developmental Brain Research, vol. 90, no. 1-2, pp. 159-167, 1995.

[108] J. Court, C. Martin-Ruiz, M. Piggott, D. Spurden, M. Griffiths, and E. Perry, "Nicotinic receptor abnormalities in Alzheimer's disease," Biological Psychiatry, vol. 49, no. 3, pp. 175-184, 2001.

[109] R. W. James, N. A. Bersinger, B. Schwendimann, and B. W. Fulpius, "Characterization of iodinated derivatives of $\alpha$ bungarotoxin," Hoppe-Seyler's Zeitschrift fur Physiologische Chemie, vol. 361, no. 10, pp. 1517-1524, 1980.

[110] A. R. L. Davies, D. J. Hardick, I. S. Blagbrough, B. V. L. Potter, A. J. Wolstenholme, and S. Wonnacott, "Characterisation of the binding of $\left[{ }^{3} \mathrm{H}\right]$ methyllycaconitine: a new radioligand for labelling $\alpha 7$-type neuronal nicotinic acetylcholine receptors," Neuropharmacology, vol. 38, no. 5, pp. 679-690, 1999.

[111] H. A. Navarro, D. Zhong, P. Abraham, H. Xu, and F. I. Carroll, "Synthesis and pharmacological characterization of $\left[{ }^{125} \mathrm{I}\right]$ iodomethyllycaconitine ([$\left.{ }^{125} \mathrm{I}\right]$ iodo-MLA). A new ligand for the $\alpha(7)$ nicotinic acetylcholine receptor," Journal of Medicinal Chemistry, vol. 43, no. 2, pp. 142-145, 2000.

[112] J. Toyohara, J. Wu, and K. Hashimoto, "Recent development of radioligands for imaging $\alpha 7$ nicotinic acetylcholine receptors in the brain," Current Topics in Medicinal Chemistry, vol. 10, no. 15, pp. 1544-1557, 2010.

[113] Y. Tanibuchi, J. Wu, J. Toyohara, Y. Fujita, M. Iyo, and K. Hashimoto, "Characterization of $\left[{ }^{3} \mathrm{H}\right] \mathrm{CHIBA}-1001$ binding to $\alpha 7$ nicotinic acetylcholine receptors in the brain from rat, monkey, and human," Brain Research, vol. 1348, no. C, pp. 200-208, 2010. 
[114] J. Toyohara, M. Sakata, J. Wu et al., "Preclinical and the first clinical studies on $\left[{ }^{11} \mathrm{C}\right] \mathrm{CHIBA}-1001$ for mapping $\alpha 7$ nicotinic receptors by positron emission tomography," Annals of Nuclear Medicine, vol. 23, no. 3, pp. 301-309, 2009.

[115] M. Sakata, J. Wu, J. Toyohara et al., "Biodistribution and radiation dosimetry of the $\alpha 7$ nicotinic acetylcholine receptor ligand $\left[{ }^{11} \mathrm{C}\right] \mathrm{CHIBA}-1001$ in humans," Nuclear Medicine and Biology. In press.

[116] J. Wu, J. Toyohara, Y. Tanibuchi et al., "Pharmacological characterization of $\left[{ }^{125} \mathrm{I}\right] \mathrm{CHIBA}-1006$ binding, a new radioligand for $\alpha 7$ nicotinic acetylcholine receptors, to rat brain membranes," Brain Research, vol. 1360, no. C, pp. 130-137, 2010. 


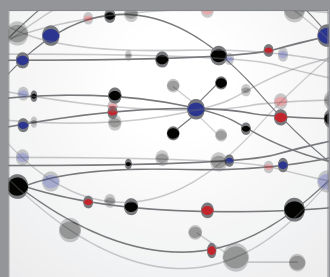

The Scientific World Journal
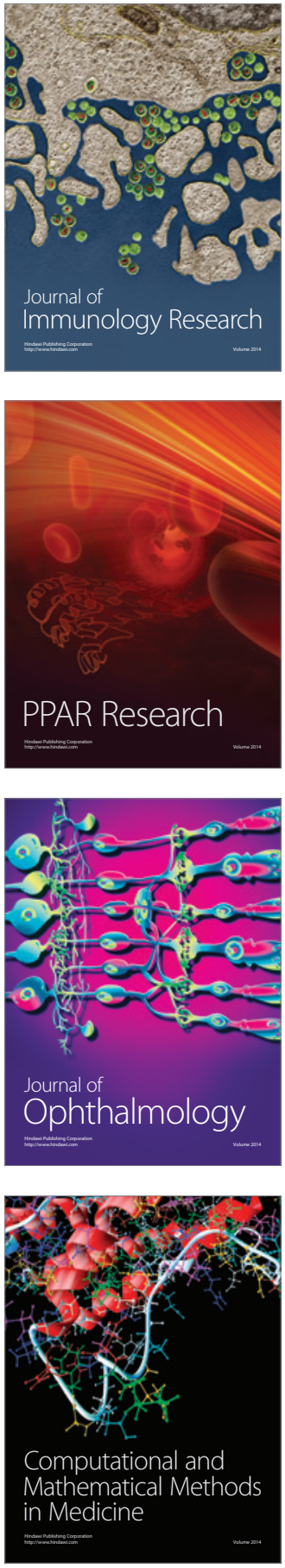

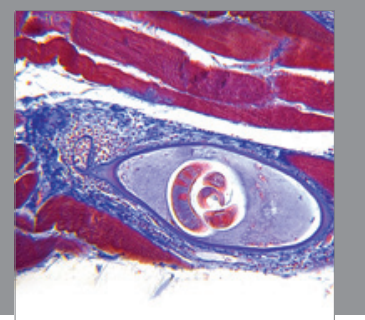

Gastroenterology

Research and Practice
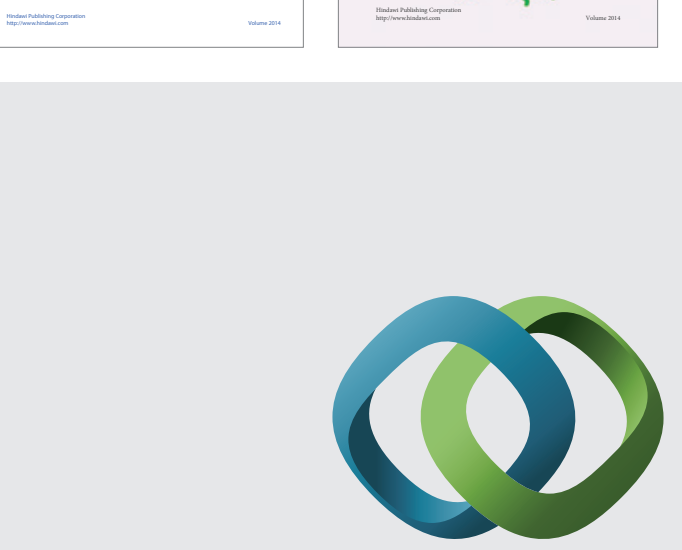

\section{Hindawi}

Submit your manuscripts at

http://www.hindawi.com
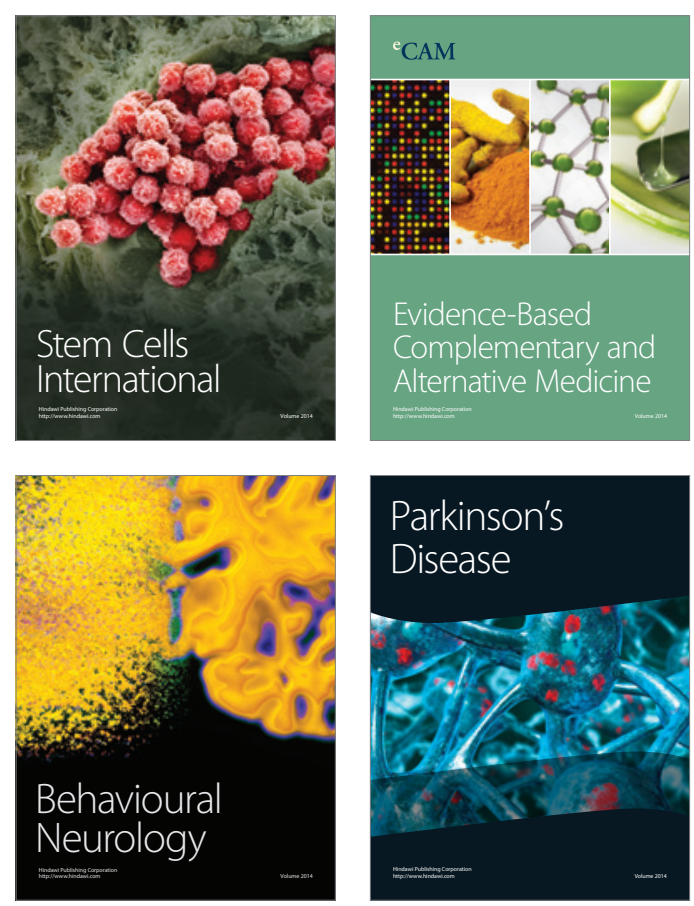

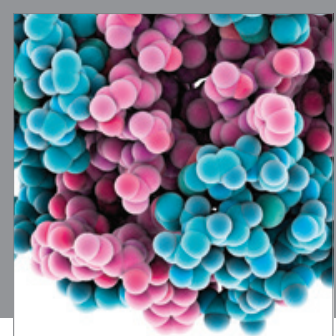

Journal of
Diabetes Research

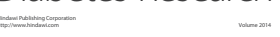

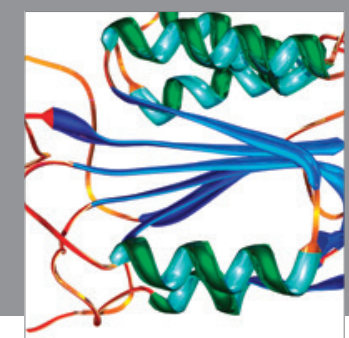

Disease Markers
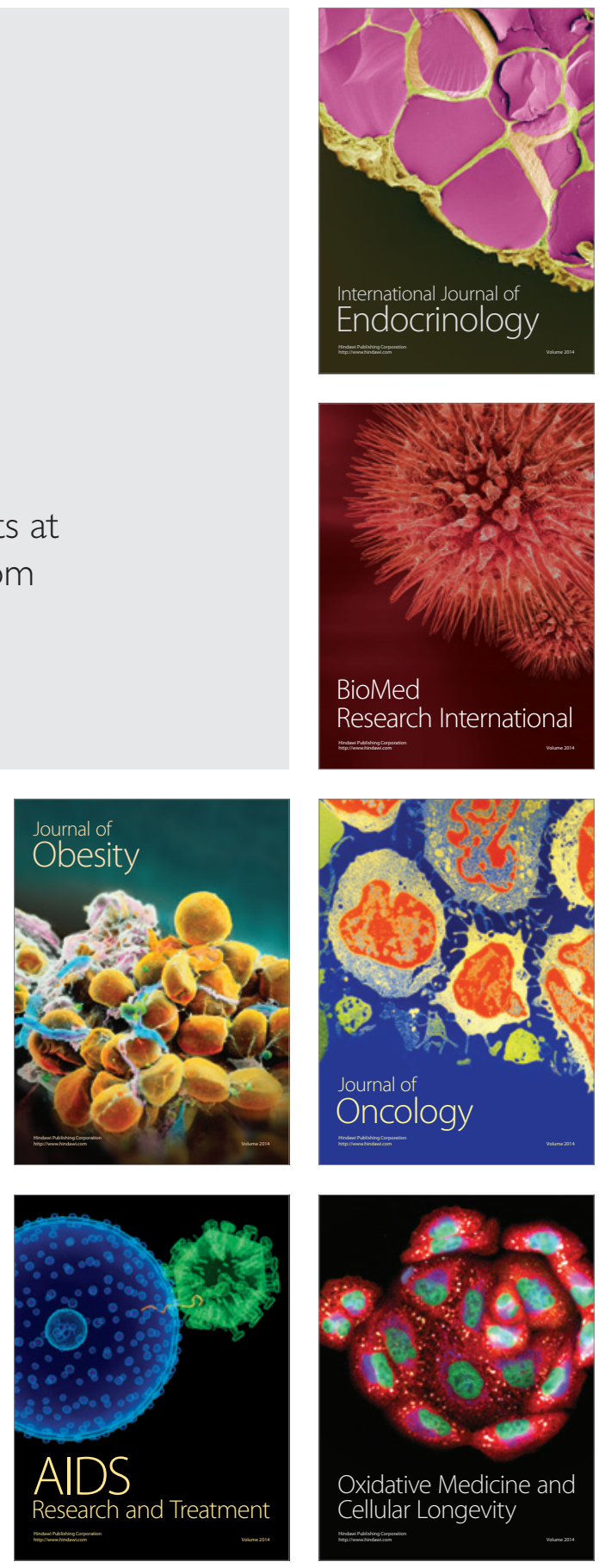